\title{
KARAKTERISASI EKSTRAK KASAR POLIFENOLOKSIDASE DARI UDANG VANAME
}

\section{Characterization of Crude Polyphenoloxidase from White Shrimp}

\author{
Medal Lintas Perceka, Tati Nurhayati*, Mala Nurilmala \\ Medal Lintas Perceka, Tati Nurhayati, Mala Nurilmala \\ Departemen Teknologi Hasil Perairan, Fakultas Perikanan dan Ilmu Kelautan, \\ Institut Pertanian Bogor, Kampus IPB Darmaga, Jalan Agatis, Bogor 16680 Jawa Barat \\ Telepon (0251) 8622909-8622906, Faks. (0251) 8622907 \\ *Korespondensi: nurhayati7870@yahoo.com \\ Diterima 06 Maret 2014/Disetujui 01 April 2014
}

\begin{abstract}
Abstrak
Polifenoloksidase (PPO) merupakan enzim yang bertanggung jawab terhadap proses diskolorasi yang disebut melanosis. Blackspot atau melanosis merupakan proses penurunan mutu yang terjadi pada udang selama penanganan dan penyimpanan postmortem. Penelitian bertujuan untuk mengevaluasi aktivitas enzim PPO udang vaname dan mengkarakterisasi enzim yang meliputi suhu, $\mathrm{pH}$, konsentrasi substrat optimum serta kinetika enzim. Enzim PPO telah berhasil diisolasi dari karapas udang vaname dengan ekstraksi buffer fosfat (1:3). Enzim ini dikarakterisasi menggunakan L-DOPA sebagai substrat spesifiknya. Ekstrak kasar PPO memiliki aktivitas optimum pada suhu $35^{\circ} \mathrm{C}, \mathrm{pH} 6$ dan konsentrasi L-DOPA sebesar 10 mM. Nilai Km dan Vmaks PPO untuk substrat L-DOPA adalah sebesar 1,17 mM dan 285,71 U.
\end{abstract}

Kata kunci: L-Dihidroksifenilalanin, Litopenaeus vannamei, melanosis, polifenoloksidase

\begin{abstract}
Polyphenoloxidase is responsible for discoloration called melanosis (blackspot). It is one of the problems that occur in shrimp during postmortem handling and storage. The objectives of this study were to evaluate the polyphenoloxidase activity and characterize this activity including temperature, $\mathrm{pH}$, substrat concentration and enzyme kinetics. PPO has been isolated from carapace of white shrimp by buffer phosphate extraction (1:3). Polyphenoloxidase (PPO) from white shrimp using L-dihidroxyphenylalanine (L-DOPA) as a spesific substrate was characterized. The crude PPO activity was optimal at temperature $35^{\circ} \mathrm{C}, \mathrm{pH} 6$ and L-DOPA concentration $10 \mathrm{mM}$. The $\mathrm{K}_{\mathrm{m}}$ and $\mathrm{V}_{\max }$ values of the PPO for L-DOPA were $1.17 \mathrm{mM}$ and 285.71 . $\mathrm{U}$ respectively.
\end{abstract}

Keywords: L-Dihidroxyphenilalanine, Litopenaeus vannamei, melanosis, polyphenoloxidase

\section{PENDAHULUAN}

Proses diskolorasi pada krustasea disebut melanosis atau blackspot. Proses ini terjadi secara alami pada saat postmortem karena adanya polimerisasi komponen fenol menjadi pigmen berwarna hitam. Melanin atau blackspot pada udang tidak berbahaya bagi konsumen, akan tetapi dapat menurunkan penerimaan konsumen dan menurunkan nilai jual terhadap komoditi tersebut. Polifenoloksidase (PPO) disebut juga fenoloksidase (PO) atau tirosinase (EC.1.14.18.1) yang mengkatalisis hidroksilasi monohidroksifenol (aktivitas monofenolase atau kresolase) dan mengoksidasi o-dihidroksifenol menjadi o-kuinon (aktivitas katekoloksidase dan difenolase). O-kuinon akan bereaksi secara nonenzimatik dengan keberadaan oksigen sehingga membentuk melanin (Kim et al. 2000).

Polifenoloksidase disintesis dari proPPO. ProPPO merupakan bentuk tidak aktif (zimogen) dari enzim PPO. ProPPO dapat diaktifkan menjadi PPO oleh enzim-enzim protease yaitu tripsin atau enzim endogenous. Sistem ini memainkan peranan penting di dalam 
respon imun, pengerasan kutikula dan proses penyembuhan luka pada krustasea (Sugumaran dan Nellaiappan 2000).

Udang merupakan sumberdaya perikanan yang memiliki nilai ekonomis penting sebagai andalan ekspor Indonesia selain tuna, cakalang dan tongkol. Volume ekspor hasil perikanan Indonesia mencapai 802 ribu ton dengan nilai US\$ 2,6 milyar pada tahun 2013 , udang memberikan sumbangan besar terhadap nilai ekspor hasil perikanan Indonesia. Komoditi udang memberikan kontribusi sebesar 33,10\% terhadap volume dan nilai ekspor hasil perikanan (KKP 2013).

Udang merupakan komoditi yang mudah mengalami kerusakan dengan masa simpan yang terbatas karena adanya pembentukan melanin atau lebih dikenal sebagai blackspot, terutama selama penanganan dan penyimpanan. Udang vaname (Litopenaeus vannamei) merupakan spesies yang memiliki nilai ekonomis penting di Indonesia karena memiliki nilai pasar yang tinggi. Studi tentang enzim PPO penyebab blackspot pada udang vanname Indonesia belum pernah dilakukan. Karakterisasi enzim PPO dari udang vaname sangat penting dilakukan untuk menemukan formula atau cara yang tepat dalam mengontrol proses pembentukan blackspot pada udang tersebut. Tujuan penelitian ini untuk mengevaluasi aktivitas enzim PPO udang vaname dan menentukan karakteristik enzim yang meliputi stabilitas terhadap suhu, $\mathrm{pH}$, konsentrasi substrat optimum, dan kinetika enzim.

\section{BAHAN DAN METODE}

\section{Bahan dan Alat}

Bahan baku yang digunakan pada penelitian adalah udang vaname (Litopenaeus vannamei) yang diperoleh dari Ever Fresh Market, Pejompongan, Jakarta Pusat, air deionisasi, bufer sodium fosfat (Merck), bufer sodium asetat (Merck), $\mathrm{NaCl}$ (Merck), Brij 35 (Merck), dan L-DOPA (Sigma). Alat yang digunakan pada penelitian ini adalah sentrifuse (Sorvall), spektrofotometer (Spectro UV-VIS 2500), pipet mikro (Axygen), inkubator (Thermoline), dan freezer.

\section{Metode Penelitian}

Penelitian dilakukan dalam dua tahap yaitu ekstraksi enzim PPO dari karapas udang dan karakterisasi enzim tersebut. Karakterisasi enzim PPO meliputi suhu, $\mathrm{pH}$, konsentrasi substrat optimum, dan kinetika enzim.

\section{Ekstraksi Enzim Polifenoloksidase (Simpson et al. 1987)}

Karapas udang dihaluskan sampai menjadi bubuk. Sampel dicampur dengan bufer fosfat $0,05 \mathrm{M} \mathrm{pH}$ 7,2 yang mengandung $1 \mathrm{M} \mathrm{NaCl}$ dan $0,2 \%$ Brij 35 (1:3). Campuran diaduk secara kontinu pada suhu $4^{\circ} \mathrm{C}$ selama 30 menit, kemudian dilakukan sentrifugasi dengan kecepatan 8.000 g pada suhu $4^{\circ} \mathrm{C}$ selama 30 menit menggunakan sentrifuse dingin.

\section{Pengukuran Aktivitas Enzim PPO (modifikasi Nirmal dan Benjakul 2009)}

Pengukuran aktivitasenzim PPO dilakukan menggunakan substrat L-DOPA. Ekstrak kasar PPO sebanyak $200 \mu \mathrm{L}$ ditambahkan dengan $1.200 \mu \mathrm{L}$ L-DOPA $15 \mathrm{mM}$ yang dilarutkan dalam air deionisasi, $800 \mu \mathrm{L}$ bufer fosfat 0,05 $\mathrm{M}, \mathrm{pH} 6$ dan $200 \mu \mathrm{L}$ air deionisasi. Campuran tersebut kemudian diinkubasi selama 3 menit pada suhu $35^{\circ} \mathrm{C}$. Pembentukan dopakrom diamati secara spektrofotometri pada panjang gelombang $475 \mathrm{~nm}$. Satu unit aktivitas PPO didefinisikan sebagai peningkatan absorbansi sebesar 0,001 pada $475 \mathrm{~nm} / \mathrm{menit} / \mathrm{mL}$.

\section{Penentuan Suhu dan pH Optimum (modifikasi Bono et al. 2010)}

Penentuan suhu optimum aktivitas enzim PPO dilakukan dengan melakukan variasi suhu inkubasi. Ekstrak kasar PPO sebanyak $200 \mu \mathrm{L}$ ditambahkan dengan $1.200 \mu \mathrm{L}$ L-DOPA $15 \mathrm{mM}$ yang dilarutkan dalam air deionisasi, $800 \mu \mathrm{L}$ bufer fosfat $0,05 \mathrm{M} \mathrm{pH} 6$ dan $200 \mu \mathrm{L}$ air deinosasi. Campuran tersebut diinkubasi pada suhu $25^{\circ} \mathrm{C}, 30^{\circ} \mathrm{C}, 35^{\circ} \mathrm{C}, 40^{\circ} \mathrm{C}$, dan $45^{\circ} \mathrm{C}$ selama 3 menit. Campuran yang telah diinkubasi 
diukur pada panjang gelombang $475 \mathrm{~nm}$.

Penentuan $\mathrm{pH}$ optimum aktivitas enzim PPO dilakukan dengan melakukan variasi pH bufer yang digunakan. Ekstrak kasar PPO sebanyak $200 \mu \mathrm{L}$ dicampur dengan $1.200 \mu \mathrm{L}$ L-DOPA $15 \mathrm{mM}$ yang dilarutkan dalam air deionisasi, $800 \mu \mathrm{L}$ bufer asetat $0,05 \mathrm{M} \mathrm{pH} 5,5$ serta bufer fosfat $0,05 \mathrm{M} \mathrm{pH} 6 ; 6,5 ; 7 ; 7,5$ dan terakhir ditambahkan $200 \mu \mathrm{L}$ air deionisasi. Campuran tersebut diinkubasi pada suhu optimum yang telah diperoleh sebelumnya selama 3 menit dan diukur pada panjang gelombang $475 \mathrm{~nm}$.

\section{Penentuan Substrat Optimum dan Kinetika Enzim (modifikasi Cong et al. 2005)}

Campuran yang terdiri dari enzim, bufer dengan $\mathrm{pH}$ optimum, air deionisasi serta L-DOPA pada konsentrasi 2,$5 ; 5 ; 7,5 ; 10 ; 12,5$; $15 \mathrm{mM}$ diinkubasi pada suhu optimum selama 3 menit. Campuran tersebut kemudian diukur pada panjang gelombang $475 \mathrm{~nm}$. Parameter kinetik yang meliputi $\mathrm{K}_{\mathrm{M}}$ dan $\mathrm{V}_{\text {MAKS }}$ ditentukan menggunakan plot Lineweaver-Burk.

\section{HASIL DAN PEMBAHASAN}

\section{Suhu Optimum Enzim PPO}

Aktivitas enzim PPO tertinggi dicapai pada suhu $35^{\circ} \mathrm{C}$ (Gambar 1). Aktivitas PPO mengalami sedikit penurunan sebelum mencapai suhu optimum, hal ini diduga energi kinetik molekulnya yang belum mencapai keadaan maksimum. Aktivitas PPO menurun drastis setelah melewati suhu $35^{\circ} \mathrm{C}$, hal ini disebabkan enzim merupakan protein yang akan mengalami denaturasi pada suhu tinggi.
Enzim mengalami kerusakan dan aktivitasnya menurun pada saat terjadinya denaturasi.

Hasil penelitian ini sama dengan penelitian Benjakul et al. (2005) dan Suhandana et al. (2013) yang menyatakan bahwa PO darikarapas udang kuruma dan PPO karapas udang windu (Penaeus monodon) menunjukkan aktivitas maksimumnya pada suhu $35^{\circ} \mathrm{C}$. Zamorano et al. (2009) menyatakan bahwa PPO dari karapas deep water pink shrimp memiliki kestabilan yang tinggi pada suhu $(30-35)^{\circ} \mathrm{C}$. Benjakul et al. (2005) menyatakan bahwa PO dari karapas udang kuruma tidak stabil pada suhu tinggi. Pemanasan pada suhu $70^{\circ} \mathrm{C}$ dan $80^{\circ} \mathrm{C}$ selama 30 menit dapat menghilangkan aktivitas $\mathrm{PO}$ udang kuruma.

Suhu optimum PPO berbagai krustasea bervariasi tergantung pada spesies dan lokasi anatomi yang digunakan. Montero et al. (2001) menyatakan bahwa suhu optimum PPO dari karapas udang tiger (Penaeus japonicus) berada pada suhu $40^{\circ} \mathrm{C}$ dan $60^{\circ} \mathrm{C}$ serta stabil pada suhu dibawah $35^{\circ} \mathrm{C}$. Hasil Garcia-Carreno et al. (2008), suhu optimum PO dari hemosianin whiteleg shrimp berada pada suhu $45^{\circ} \mathrm{C}$. Menurut Fan et al. (2009), suhu optimum PO dari hemosianin kepiting Charybdis japonica berada pada suhu $40^{\circ} \mathrm{C}$. Fan et al. (2011) menyatakan bahwa suhu optimum PO dari brine shrimp (Artemia sinica) berada pada suhu $50^{\circ} \mathrm{C}$. Enzim PPO dari karapas udang vaname (L.vannamei) memiliki suhu optimum yang lebih rendah dibandingkan dengan krustasea lainnya yang telah diteliti. Perbedaan ini diduga disebabkan oleh perbedaan bobot molekul, spesies, suhu habitat, musim, dan perbedaan

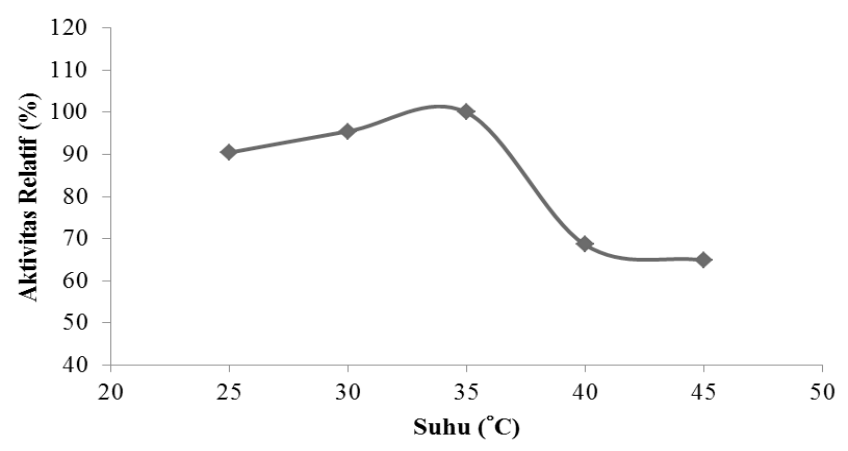

Gambar 1 Suhu optimum PPO udang vaname (L. vannamei) 
kondisi pertahanan tubuh.

\section{pH Optimum Enzim PPO}

Aktivitas enzim PPO udang vaname mencapai maksimum pada $\mathrm{pH}$ 6, kemudian ketika nilai pH dinaikkan di atas 6, aktivitasnya mulai menurun (Gambar 2). Nilai pH akan menentukan konformasi enzim berdasarkan keadaan asam amino pada sisi aktifnya. Enzim PPO pada pH 6 diduga memiliki konformasi yang paling sesuai dengan substratnya membentuk kompleks enzim-substrat yang tepat sehingga dapat menghasilkan produk secara maksimal.

Nilai pH optimum PPO dari karapas udang vaname lebih rendah dibandingkan dengan PO karapas udang kuruma yang memiliki pH optimum 6,5 (Benjakul et al. 2005), PO hemosianin white leg shrimp memiliki pH optimum 7,6 (Garcia-Carreno et al. 2008); PPO hemosianin kepiting Charybdis japonica (Fan et al. 2009), PO dari Artemia sinica (Fan et al. 2011) serta PPO dari karapas Penaeus monodon (Suhandana et al. 2013) yang memiliki pH optimum 7; serta lebih tinggi dari PPO karapas deep water pink shrimp (Parapenaeus longirostris) yang memiliki pH optimum 4,5. Montero et al. (2001) menyatakan bahwa pH optimum PPO dari karapas Penaeus japonicus berada pada pH 5 dan 8 tetapi paling stabil pada kisaran pH basa. Benjakul et al. (2005) menyatakan bahwa PO cephalotorax kuruma prawn stabil pada kisaran $\mathrm{pH}$ 3-10. Perbedaan nilai $\mathrm{pH}$ optimum diduga oleh perbedaan spesies, perbedaan kondisi pertahanan tubuh yang meliputi habitat dan invasi patogen, serta perbedaan konformasi enzim pada bagian sisi aktifnya.

\section{Kinetika Enzim}

Enzim PPO yang menggunakan L-DOPA sebagai substrat spesifiknya mencapai aktivitas maksimum pada saat konsentrasinya $10 \mathrm{mM}$. Aktivitas PPO berada pada keadaan yang relatif konstan ketika konsentrasi L-DOPA di atas $10 \mathrm{mM}$ (Gambar 3). Semakin tinggi

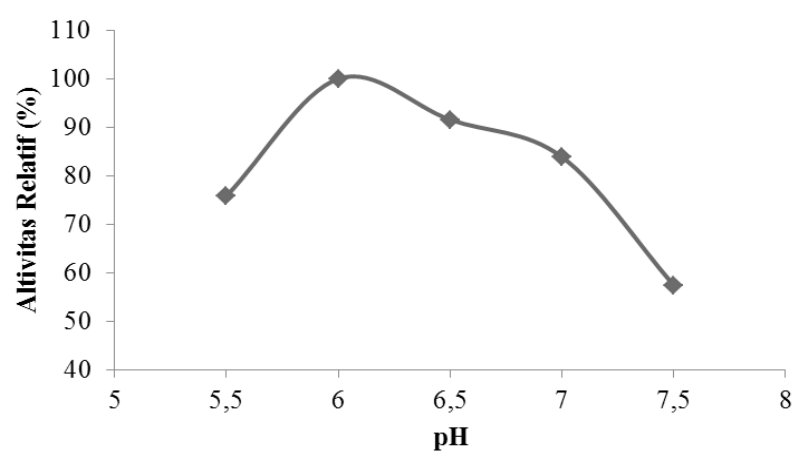

Gambar 2 pH optimum PPO udang vaname (L.vannamei).

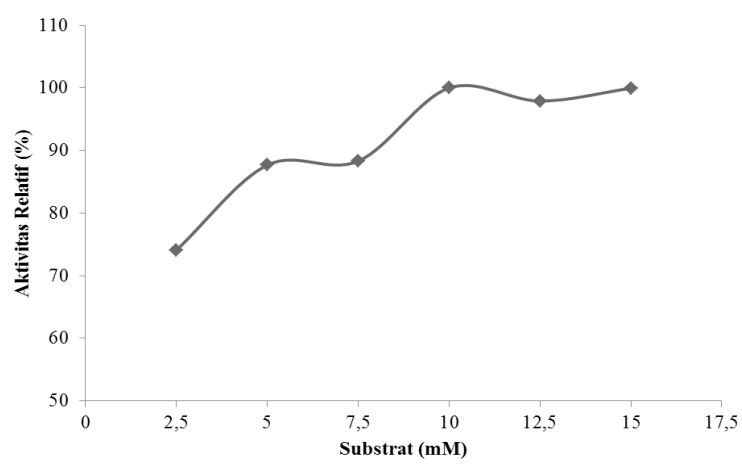

Gambar 3 Konsentrasi substrat optimum PPO udang vaname (L. vannamei). 


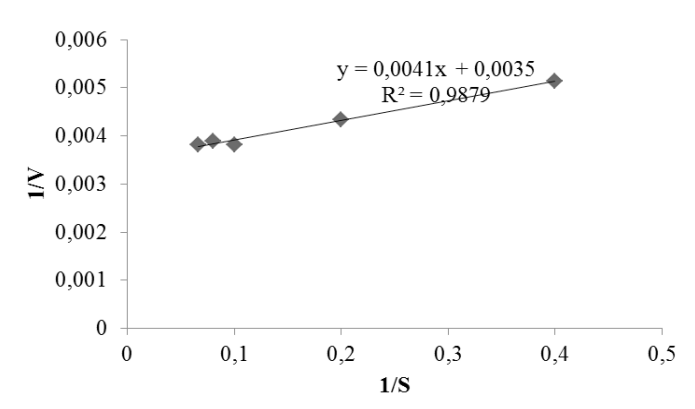

Gambar 4 Persamaan Lineweaver-Burk untuk menentukan nilai $\mathrm{K}_{\mathrm{m}}$ dan $\mathrm{V}_{\text {maks }}$

konsentrasi substrat maka kecepatan enzim semakin meningkat dan pada saat tertentu akan mencapai keadaan konstan.

Nilai $\mathrm{K}_{\mathrm{m}}$ dan $\mathrm{V}_{\text {maks }}$ ditentukan berdasarkan persamaan Lineweaver-Burk dengan membuat grafik $1 /[\mathrm{S}]$ sebagai sumbu $\mathrm{x}$ dan $1 / \mathrm{V}$ sebagai sumbu y (Gambar 4). Berdasarkan persamaan garis tersebut diperoleh nilai $\mathrm{K}_{\mathrm{m}}$ sebesar $1,17 \mathrm{mM}$ dan $\mathrm{V}_{\text {maks }}$ sebesar 285,71 U. Nilai $\mathrm{K}_{\mathrm{m}}$ menyatakan tetapan disosiasi kompleks enzim-substrat. Semakin kecil nilai Km menunjukkan kompleks enzim-substrat semakin baik sehingga enzim memiliki afinitas yang tinggi terhadap substrat.

Fan et al. (2009) menyatakan bahwa nilai Km PO dari hemosianin kepiting Charybdis japonica untuk substrat L-DOPA adalah 2,90 $\mathrm{mM}$ dan tirosin 7,33 mM. Fan et al. (2011) menyatakan bahwa nilai Km PO brine shrimp (Artemia sinica) yaitu sebesar 4,2 mM untuk substrat L-DOPA dan 10,9 mM untuk katekol. Suhandana et al. (2013) menyatakan nilai Km PPO dari karapas udang black tiger (Penaeus monodon) untuk substrat L-DOPA adalah 5,42 mM. Gimenez et al. (2010) menyatakan bahwa enzim PO dari jeroan lobster Norway (Nephrops norvegicus) memiliki afinitas yang lebih tinggi dibandingkan dengan PO dari karapas lobster untuk substrat katekol. Nilai $\mathrm{K}_{\mathrm{m}}$ PO dari jeroan lobster Norway adalah sebesar 5,97 dan karapas sebesar 19,40 mM. Nilai $\mathrm{K}_{\mathrm{m}}$ PPO karapas udang vaname adalah yang paling rendah dibandingkan dengan krustasea lainnya, hal ini menunjukkan bahwa enzim PPO dari karapas udang vaname memiliki afinitas yang paling tinggi terhadap substrat L-DOPA dibandingkan dengan spesies lainnya.

Golongan insekta, enzim PPO dklasifikasikan menjadi 3 golongan yaitu golongan laccase (E.C 1.10.3, p-difenol: O2 oksidoreduktase), golongan catecholoxidase (E.C.1.10.3.1, difenol: O2 oksidoreduktase) dan golongan tirosinase (E.C.1.14.18.1 monofenol, L-DOPA: O2 oksidoreduktase). PPO golongan tirosinase dapat mengoksidasi monofenol dan difenol, sedangkan golongan laccase dan catecholoxidase menunjukkan afinitas yang tinggi terhadap difenol (Cong et al. 2005).

\section{KESIMPULAN}

Aktivitas optimum enzim PPO pada suhu $35^{\circ} \mathrm{C}, \mathrm{pH}$ 6, dan konsentrasi L-DOPA sebesar $10 \mathrm{mM}$. Enzim PPO dari karapas udang vaname memiliki afinitas yang tinggi terhadap substrat L-DOPA dengan nilai $\mathrm{K}_{\mathrm{m}}$ dan $\mathrm{V}_{\text {maks }}$ yaitu $1,17 \mathrm{mM}$ dan 285,71 $\mathrm{U}$.

\section{DAFTAR PUSTAKA}

Benjakul S, Visessanguan W, Tanaka M. 2005. Properties of phenoloxidase isolated from the cephalothorax of kuruma prawn (Penaeus japonicus). Food Biochemistry 29(5): 470-485.

Bono G, Badalucco C, Corrao A, Cusumano S, Mammina L, Palmegiano GB. 2005. Effect of temporal variation, gender, and size on curticle polyphenoloxidase activty in-deep water rose shrimp (Parapeneus longirostris). Food Biochemistry 29(5): 470-485.

Cong R, Sun W, Liu G, Fan T, Meng X, Yang L, Zhu L. 2005. Purification and caracterization of phenoloxidase from clam Ruditapes philippinarium. Fish and Shellfish Immunology 18(1): 61-70.

Fan T, Zhang Y, Yang L, Yang X, Jiang G, Yu M,Cong R. 2009. Identification and characterization of hemocyanin-derived phenoloxidase from the crab Charybdis japonica. Comparative Biochemistry and Physiology 152(2): 144-149.

Fan T, Jing Z, Fan X, Yu M, Jiang G. 2011. Purification and characterization of phenoloxidase from brine shrimp Artemia sinica. Acta Biochemistry and Biophysic Science 43(9): 722-728.

Garcia-Carreno FL, Cota K, Toro MAND. 2008. 
Phenoloxidase activity of hemocyanin in whiteleg shrimp Penaeus vannamei: conversion, characterization of catalytic properties, and role in postmortem melanosis. Journal of Agricultural and Food Chemistry 56(15): 6454-6459.

Gimenez B, Martinez-Alvarez O, Montero P, Gomez-Guillen MDC.2010. Characterization of phenoloxidase activity of carapace and viscera from cephalothorax of Norway lobster (Nephrops norvegicus). Food Science and Technology 43(8): 1240-1245.

[KKP] Kementerian Kelautan dan Perikanan. 2013. Kelautan dan Perikanan dalam Angka. Jakarta: Pusat Data, Statistik dan Informasi, Sekretariat Jenderal, Kementerian Kelautan dan Perikanan.

Kim J, Marshall MR, Wei C. 2000. Polyphenoloxidase. Di dalam: Haard NF, Simpson BK, editor. Seafood Enzymes: Utilization and Influence on Postharvest Seafood Quality. New York: Marcel Dekker, Inc. hlm 271-316.

Montero P, Avalos A, Perez-Mateos M. 2001. Characterization of polyphenoloxidase of prawns (Penaeus japonicus). Alternatives to inhibition: additives and high-pressure treatment. Food Chemistry 7: 317-324.

Nirmal NP, Benjakul S. 2009. Effect of ferulic acid on inhibition of polyphenoloxidase and quality changes of Pacific white shrimp (Litopenaeus vannamei) during iced storage. Food Chemistry 116: 323-331.

Simpson BK, Marshall MR, Otwell WS. 1987. Phenoloxidase from shrimp (Penaeus setiferus): purification and some properties. Journal of Agricultural and Food Chemistry 35: 918-921.

Sugumaran M, Nellaiappan K. 2000. Characterization of a new phenoloxidase inhibitor from the cuticle of Manduca sexta. Biochemical and Biophysical Research Communication 268(2): 379-383.

Suhandana M, Nurhayati T, Ambarsari L. 2013. Karakterisasi ekstrak kasar enzim polyphenoloxidase dari udang windu (Penaeus monodon). Jurnal Ilmu dan Teknologi Kelautan Tropis 5(2): 343-354.

Zamorano JP, Martinez-Alvarez O, Montero P, Gomez-GuillenMDC.2009. Characterisation and tissue distribution of polyphenoloxidase of deep water pink shrimp (Parapenaeus longirostris). Food Chemistry 112: 104-111. 